\title{
MANAGING FURROW IRRIGATION METHOD IN CORN SMALL HOLDINGS
}

\author{
Amer, K. H. ${ }^{(1)}$, Samak, A. A. ${ }^{(2)}$, and Hegazi, E. H. ${ }^{(3)}$
}

\section{ABSTRACT}

A field study on corn using furrow irrigation was carried out in northern Egypt on a clay loam soil with $1.2 \mathrm{~g} \mathrm{~cm}^{-3}$, average soil bulk during 2015 season in Shibin El-Kom area, Egypt. The main aim of this work is to study the changing of irrigation rate (10.71 and $5.35 \mathrm{~m}^{3} \mathrm{~h}^{-1}$ ) and fertilizer application (in complete irrigation time and half wave) on two different slopes (0.05 and $0.1 \%$ ) of corn field in order to improve furrow irrigation method in small holdings. Corn seeds (Hi-Tech 2031) were planted on May 13, 2015 and received eight irrigations during the growing season. Application efficiency $\left(E_{a}\right)$ was highly achieved by applying $10.71 \mathrm{~m}^{3} \mathrm{~h}^{-1}$ and improved by all treatments in second irrigation due to increasing initial soil moisture content compared to first irrigation. Storage efficiency $\left(E_{s}\right)$ was properly achieved by applying all treatments except $10.71 \mathrm{~m}^{3} \mathrm{~h}^{-1}$ inflow rate under $0.05 \%$ furrow slope because $7 \%$ deficit was occurred. The results showed that, average of corn yield, green forage yield, 100-grain weight, number of rows per ear and number of grains per row increased by decreasing furrow slope, decreasing inlet flow rate, and nitrogen application after offering half wave. Nitrogen application after offering half wave was achieved high nitrogen $(N)$ concentration in corn root zone. The results indicated that corn yield increased by 8.90, 0.39 and $5.74 \%$ by applying furrow slope 0.05\% relative to $0.1 \%, 5.35 \mathrm{~m}^{3} \mathrm{~h}^{-1}$ inlet flow rate relative to $10.71 \mathrm{~m}^{3} \mathrm{~h}^{-1}$ and nitrogen application after offering half wave along furrow relative to nitrogen application with the beginning of irrigation, respectively.

(1) Professor, Agric. Eng. Dept., Menoufia University

(2) Lecturer, Agric. Eng. Dept., Menoufia University

(3) Demonstrator, Agric. Eng., Dept., Menoufia University 


\section{INTRODUCTION}

Urface irrigation systems are the most popular methods for irrigating crops in Egypt and worldwide (Amer, 2009; El Awady et al., 2009; Koech et al., 2010). Surface irrigation efficiency is generally low in comparison to sprinkler and trickle irrigation systems. Using gated irrigation pipe to flow water from field upstream towards downstream ends improves the performance of surface irrigation system. Gated pipes provide a good control technique over the irrigation stream size. In gated pipes system, irrigation water flows from orifices (gates) which are regularly spaced along the pipeline (Smith et al., 1986). Furrow irrigation, is one of the oldest known techniques of surface irrigation, water is conveyed through small channels with a gentle slope towards the downstream end. The spacing of these channels generally correspond to the spacing of the crop to be established (Koech et al., 2010). The water infiltrates the soil both vertically and horizontally (Amer, 2009). Furrow irrigation requires lower capital investment, less technical knowledge and greater labor than most sprinkle and trickle irrigation systems (DL Bjorneberg, 2013).Surface irrigation process includes four phases: advance, storage, depletion, and recession (Holzapfel et al., 1984; Walker and Skogerboe, 1987; Alazba, 1999). The opportunity time for water to infiltrate at any point along the field is equal to the time interval between the advance and recession curves (Merriam and Keller (1978); Holzapfel et al., 1984; Foroud et al., 1996; Rodriguez, 2003).

Corn (Zea Mays) is one of the most important cereals both for human and animal consumption and grown for grain and forage. Corn crop response to water deficit was reported by Dooronbos and Kassam (1979). They concluded that corn is tolerant to water deficit during vegetative and ripping stages. But, great grain yield reduction is caused by water deficit during flowering period. Musick and Duseek (1980) reported that seasonal corn evapotranspiration (ET) values were between $667 \mathrm{~mm}$ and $789 \mathrm{~mm}$ under fully-irrigated at Bushland, USA from level-basin studies for 3 years with corresponding grain yields of 9.5 to $10.9 \mathrm{Mg} \mathrm{ha}^{-1}$, respectively. They also reported that fully-irrigated seasonal of water use efficiency (grain yield per unit ET) values were 1.25 to $1.46 \mathrm{~kg} \mathrm{~m}^{-3}$. Eck 
(1984) reported that the ET of corn at Bushland varied from $783 \mathrm{~mm}$ to $1003 \mathrm{~mm}$ over 4 years of study conducted in both graded furrow and level basin plots, with maximum yield levels from 8.4 to $13.2 \mathrm{Mg} \mathrm{ha}^{-1}$, respectively. Undersander et al., (1985) conducted sprinkler irrigation studies with corn at Bushland and Texas under similar conditions. They reported that a grain yield of $5.54 \mathrm{Mg} \mathrm{ha}^{-1}$ obtained under $791 \mathrm{~mm}$ water use. Howell et al., (1997) working on corn (Zea Mays L. cv. PIO 3245) at Bushland, Texas, on clay loam soil, in semi-arid environment, found that corn yields exceeding $1.4 \mathrm{~kg} \mathrm{~m}^{-2}$ at $15.5 \%$ water content, were achieved in 1994, and yields exceeding $1.3 \mathrm{~kg} \mathrm{~m}^{-2}$ were even achieved with the late planting date and the late insect problems in 1993 under microirrigation systems. They recorded a linear relation between grain yield and water use in deficit irrigation condition $\left(r^{2}=0.929\right)$ for both seasons.

Precision land leveling and irrigation water discharge are the main factors affecting directly irrigation efficiency of surface irrigation system. Laser leveling increases field irrigation efficiency, saves water, increases yield and consequently increases crop-water use efficiency (Awad and Gomaa, 2004). There are many engineering factors affecting the water infiltrated depth along furrow and the uniformity in surface irrigation systems such as inlet flow and furrow slope (Mohammed, 2008).

Excessive application of nitrogen and unreasonable management of water and nitrogen lead to nitrate pollution of groundwater and surface water in this region (Zhu and Chen 2002). Nitrogen is a mobile nutrient in soilplant systems. Improvement of crop management practices can increase nitrogen $(\mathrm{N})$ use efficiency in crops. These improved practices include creating favorable environmental conditions for crops, which lead to higher nitrogen $(\mathrm{N})$ uptake and utilization and consequently higher yields. Appropriate sources, efficient methods of application and application timing when crops absorb maximum amounts are important nitrogen $(\mathrm{N})$ management strategies (Fageria and Baligar, 2005). The general practice of nitrogen application in Egypt is through broadcasting of urea. Under the uneven soil surface conditions, the applied nitrogen is washed away from higher levels to lower levels with irrigation water and is leached 
down to low lying depressions, resulting in low fertilizer-use efficiency (Jat et al., 2006).The absorption of nitrogen by plants plays an important role in their growth. Consequently, nitrogen fertilization has been a powerful tool for increasing the yield of cultivated plants, such as cereals(Gallais and Hirel, 2004).The optimum fertilizer increases grain yield and improves grain quality in terms of protein and starch contents(Abdul Rehman et al., 2011). Nitrogen must be used in balance with other potential limitations for yield production, particularly water (Cetin and Akinci, 2015).

The objective of this research is to study corn production related to furrow inlet flow rate, slope and nitrogen application method and their interactions. Besides that is to study irrigation water and nitrogen distributions along furrow.

\section{MATERIALS AND METHODS}

Field experiment was conducted at an arid site in northern Egypt (Shibin El-Kom area, $17.9 \mathrm{~m}$ above sea level, $30^{\circ} 32 / \mathrm{N}, 31^{\circ} 03 / \mathrm{E}$ ). The soil of the experimental site was classified as clay loam with $1.2 \mathrm{~g} \mathrm{~cm}^{-3}$, average soil bulk density for $0.6 \mathrm{~m}$ soil depth. Some physical and mechanical analysis of the soil was determined according to (Black, 1982). The soil samples were collected until $60 \mathrm{~cm}$ soil depth to determine mechanical analysis, field capacity, permanent wilting point, density and organic matter for each depth and the results are shown in Table 1. Some chemical properties of soil located in the experimental site are shown in Table 2.

Table 1: Soil field capacity, soil permanent wilting point, soil bulk density and organic matter percent with soil depth

\begin{tabular}{|c|c|c|c|c|c|c|c|}
\hline \multirow{2}{*}{$\begin{array}{c}\text { Soil } \\
\text { depth } \\
\mathrm{cm}\end{array}$} & \multicolumn{3}{|c|}{$\begin{array}{c}\text { Particles size } \\
\text { distribution \% }\end{array}$} & $\begin{array}{c}\text { Bulk } \\
\text { density }\end{array}$ & $\begin{array}{c}* \mathrm{~F} . \mathrm{C} \\
\left(\mathrm{gm} \mathrm{gm}^{-1}\right)\end{array}$ & $\begin{array}{c}* * \text { P.W.P } \\
\left(\mathrm{gm} \mathrm{gm}^{-1}\right)\end{array}$ & $\begin{array}{c}\text { Organic } \\
\text { matter } \\
\text { percent (\%) }\end{array}$ \\
\cline { 2 - 5 }$\left(\mathrm{gm} \mathrm{cm}^{-3}\right)$ & Silt & Clay & & & \\
\hline $0-20$ & 25.00 & 30.20 & 44.80 & 1.18 & 0.326 & 0.176 & 2.60 \\
\hline $20-40$ & 17.79 & 31.14 & 51.07 & 1.21 & 0.356 & 0.178 & 1.80 \\
\hline $40-60$ & 15.68 & 27.42 & 56.90 & 1.22 & 0.350 & 0.174 & 1.40 \\
\hline Average & 19.49 & 29.59 & 50.90 & 1.20 & 0.344 & 0.176 & 1.93 \\
\hline
\end{tabular}

*F.C is field capacity and **P.W.P is permanent wilting point. 
Table 2: Some chemical properties of the experimental field soil

\begin{tabular}{|c|c|c|c|c|c|c|c|c|c|}
\hline \multirow{2}{*}{$\begin{array}{c}\text { Depth } \\
\mathrm{cm}\end{array}$} & $\mathrm{PH}$ & \multirow{2}{*}{$\begin{array}{c}\mathrm{EC} \\
\end{array}$} & & \multicolumn{3}{|c|}{ Soluble cations, meq. $\mathrm{l}^{-1}$} & \multicolumn{3}{c|}{ Soluble anions, meq. $\mathrm{I}^{-1}$} \\
\cline { 4 - 10 } & & $\mathrm{ds}^{-1}$ & $\mathrm{~K}^{+}$ & $\mathrm{Ca}^{+2}$ & $\mathrm{Mg}^{+2}$ & $\mathrm{Cl}^{-1}$ & $\mathrm{HCo}_{3}^{-2}$ & $\mathrm{So}_{4}{ }^{-2}$ \\
\hline $0-20$ & 8.64 & 0.29 & 3.23 & 0.07 & 0.30 & 0.10 & 1.10 & 1.50 & 1.10 \\
\hline $20-40$ & 8.70 & 0.30 & 3.37 & 0.06 & 0.20 & 0.20 & 1.10 & 1.60 & 1.13 \\
\hline $40-60$ & 8.74 & 0.33 & 3.68 & 0.02 & 0.10 & 0.20 & 1.20 & 1.70 & 1.10 \\
\hline
\end{tabular}

Experimental plot was plowed twice orthogonally using chisel plow then the field leveling was conducted using laser leveling machine. Two levels of field were chosen as subplots design. $0.05 \%$ leveling as a first subplot and $0.1 \%$ leveling as second subplot. Every sub plot was divided into eight parts. Each part contains 4 furrows. The dimensions of each furrow were $60 \mathrm{~m}$ length and $0.70 \mathrm{~m}$ width, with a distance of $0.70 \mathrm{~m}$ between every two consecutive parts as belted area. The experimental treatments were randomized arranged as shown in Fig.1.

Corn seeds (Hi-Tech 2031) were planted on May 13, 2015 using row corn planter and terminated on August 31, 2015. Distance between furrows was $70 \mathrm{~cm}$ and between seeds in furrow was $20 \mathrm{~cm}$. Super phosphate calcium and potassium fertilizers were applied by strewing manually after plowing and leveling of experimental soil. The nitrogen fertilizers (Calcium Nitrate 33.5\%) were added over three stages in a rate of $852 \mathrm{~kg}$ $\mathrm{ha}^{-1}$ by venturi injector. The first stage ( $20 \%$ of total amount) was applied with planting, the second stage (40\% of total amount) was applied with the first irrigation and the third stage (40\% of total amount) was applied with the second irrigation. Venturi injector was fitted to inject fertilizer into irrigation water.

Experimental area was irrigated using modified surface irrigation system by gated pipes at upstream of each furrow. The distance between two consecutive gates was $0.70 \mathrm{~m}$. The gated pipes were fitted together by their couplers. The last one of the gated pipe was equipped with a plug at its end. Gate pipe orifices were manually controlled to be full and half openings. Full and half openings of the gate delivered a discharge of 10.71 and $5.35 \mathrm{~m}^{3} \mathrm{~h}^{-1}$, respectively. In the field, the discharge was 
measured by using catch cans. Velocity of water flow in a pipe line ranged between 1.5 and $2.4 \mathrm{~m} / \mathrm{s}$ (Hastings, Co. 1986).

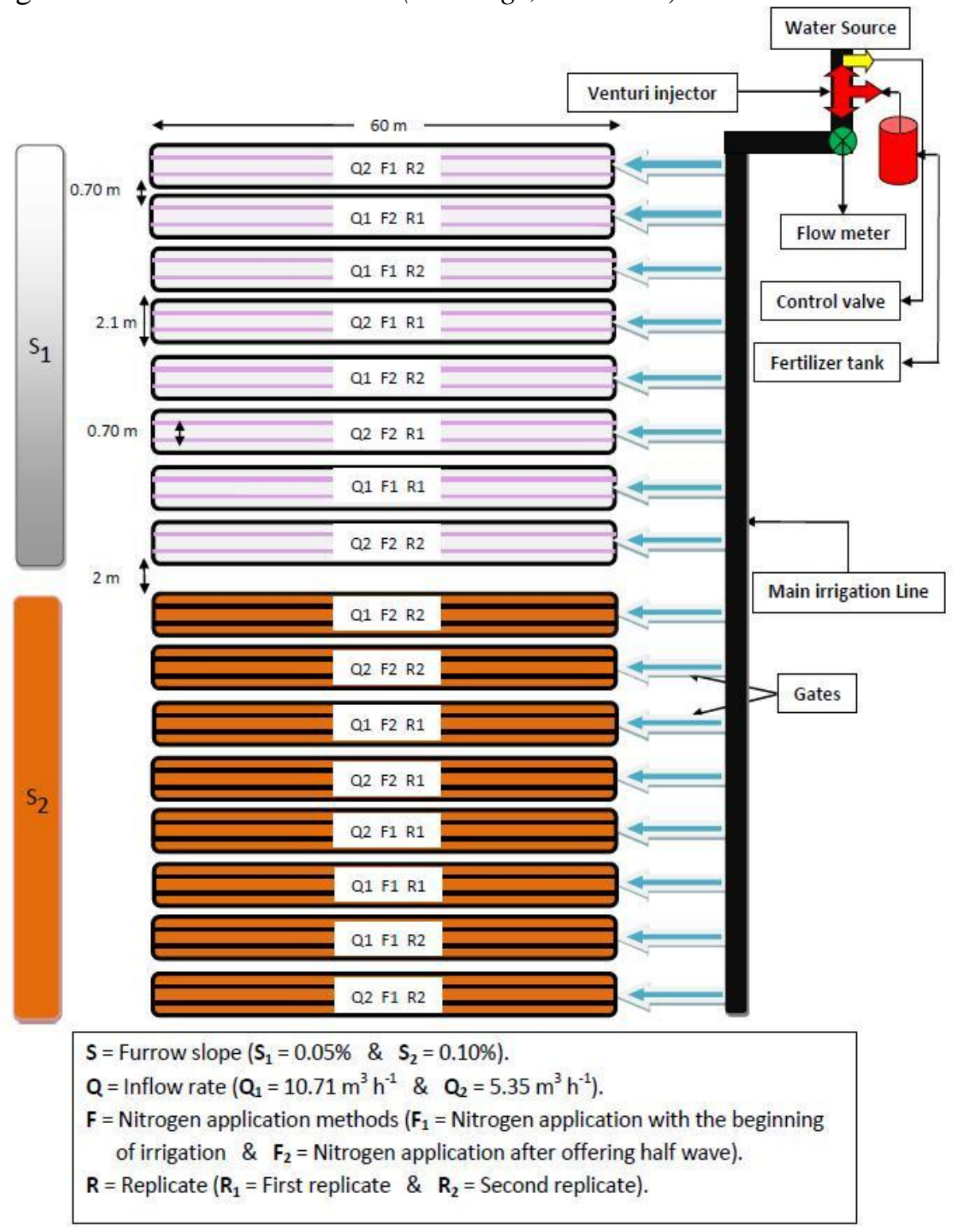

Fig. 1: Schematic diagram of the experimental layout

Corn crop was irrigated eight times along the growing season. The first irrigation was called Mahaya and which was applied 15 days after sowing. The $2^{\text {nd }}, 3^{\text {rd }}, 4^{\text {th }}, 5^{\text {th }}, 6^{\text {th }}, 7^{\text {th }}$ and $8^{\text {th }}$ irrigations were $29,43,56,67$, 
78, 89 and 99 days after planting, respectively. Water flow was left 10 and $5 \mathrm{~min}$ as storage at $0.05 \%$ and $0.1 \%$ furrow slope, respectively. Harvesting of corn crop was started 111 days after planting when the grains were fully mature. Corn samples were collected at a rate of $1.4 \mathrm{~m}^{2}$ from each $10 \mathrm{~m}$ of furrow length (10 sticks from the central lines). After that the samples were left exposed to the open-air dry.

Soil samples were collected just day before irrigation. Also, soil samples were collected two days after irrigation. The samples were collected every $15 \mathrm{~m}$ of furrow length at each length point; three samples were collected at $0-20,20-40$, and $40-60 \mathrm{~cm}$ of soil depths. The soil samples collecting were done with first, second, and third irrigations. Soil samples were taken using a stainless steel auger (Estefan, et al., 2013).

Soil moisture content was found by collecting soil samples and putting them in drying oven with $105^{\circ} \mathrm{C}$ for 24 hours. Nitrogen content ratio was determined using collecting soil samples after air-dried. Soil samples were gently crushed and sieved to digest the samples, then nitrogen content ratio was measured. Total soil (N) (mainly organic) is generally measured after wet digestion using the well-known Kjeldahl procedure (Estefan et al., 2013).

The schedule irrigation depth (d) to be applied was determined in millimeters per irrigation interval based on the average of volumetric moisture content of soil root depth before and after irrigation as follows:

$$
d=\left(\theta_{F}-\theta_{i}\right) D \cdot----
$$

Where $(\mathrm{d})$ is scheduling irrigation depth in $\mathrm{mm},\left(\theta_{\mathrm{F}}\right)$ is volumetric water content at field capacity $\mathrm{m}^{3} \mathrm{~m}^{-3},\left(\theta_{\mathrm{i}}\right)$ volumetric water content before irrigation in $\mathrm{m}^{3} \mathrm{~m}^{-3}$, and (D) is wetted soil root depth in $\mathrm{mm}$.

The schedule parameter $(\alpha)$ determined from the following equation (Amer, 2007):

$$
\alpha=\frac{1}{C V}\left(\frac{d}{\mu}-1\right)----
$$


Where $(\mathrm{CV})$ is the coefficient of variation in decimal and $(\mu)$ is average infiltrated irrigation depth in $\mathrm{mm}$.

Application efficiency $\left(\mathrm{E}_{\mathrm{a}}\right)$ was determined as the ratio of water stored in the root zone to the total water applied when no runoff occurred in blocked furrow. In non uniformity condition, $\left(\mathrm{E}_{\mathrm{a}}\right)$ can be determined according to (Amer, 2010) as follows:

$$
E_{a}=1-\frac{(1.725-\alpha)^{2} C V}{6.9}----(3)
$$

The storage efficiency $\left(\mathrm{E}_{\mathrm{S}}\right)$ can be expressed in the distribution according to (Amer, 2010) as follows:

$$
E_{s}=1-\frac{(1.725+\alpha)^{2} C V}{6.9(1+\alpha C V)}----(4)
$$

The uniformity coefficient (UC) can be expressed in power distribution for water infiltrated depth which determined according to (Amer, 2009) as follows:

$$
U C=1-0.86 C V----(5)
$$

The distribution uniformity (DU) can be expressed for $100 \%$ data determined from three empirical foregoing functions according to (Amer, 2009) as follows:

$$
D U=1-1.33 C V----(6)
$$

The coefficient of variation (CV) can be expressed according to (Amer, 2009) as follows:

$$
C V=\frac{1}{\bar{Z}} \sqrt{\frac{(Z-\bar{Z})^{2}}{N-1}}----(7)
$$

Where $(\mathrm{CV})$ is coefficient of variation, $(\mathrm{Z})$ is infiltrated depth in $\mathrm{mm},(\bar{Z})$ is average of infiltrated depth in $\mathrm{mm}$, and $(\mathrm{N})$ is total number of stations.

\section{RESULTS AND DISCUSSION}

\subsection{Irrigation depth along furrow and efficiency}

Irrigation depth along furrow and its evaluation parameters for first and second irrigations with two different inflow rates and slopes was 
measured and illustrated in Table 3. The results showed that irrigation depth was significantly, affected by furrow slope and inlet flow rate. The minimum infiltrated depth $\left(Z_{\text {min }}\right)$ was occurred at the upstream end because most of water was accumulated at the downstream end of the furrow which had more infiltrated opportunity time in relative to upstream end. Infiltrated irrigation depth, except $10.71 \mathrm{~m}^{3} \mathrm{~h}^{-1}$ treatment under $0.05 \%$ furrow slope, was increased in first irrigation after corn seeding, relative to second irrigation which was represented the consecutive other irrigations, because all corn irrigations except first one were applied with higher initial soil moisture content. Infiltrated irrigation depth increased significantly by decreasing inlet flow rate due to increasing advance time. It increased as furrow slope increased due to increasing water recession time along furrow, except for $10.71 \mathrm{~m}^{3} \mathrm{~h}^{-1}$ in second irrigation. The results of $10.71 \mathrm{~m}^{3} \mathrm{~h}^{-1}$ inflow rate treatment during second irrigation showed that irrigation depth were decreased by increasing of furrow slope due to rapid water movement of water during advance and recession stages. These results are in agreements of Amer, (2009) and Hassan et al., (2013). Using 0.05\% furrow slope, evaluation parameters were significantly improved using 10.71 and $5.35 \mathrm{~m}^{3} \mathrm{~h}^{-1}$ inlet flow rate for first and second irrigations, respectively. Results concluded that the 10.71 and $5.35 \mathrm{~m}^{3} \mathrm{~h}^{-1}$ inflow rate was suitable to apply in second irrigation when initial soil moisture content increased from 50 to $65 \%$ of available water. Uniformity coefficient $(U C)$ as well as distribution uniformity $(D U)$ as related to coefficient of variation $(C V)$ affected when slope and inflow rate change and achieved acceptable value for all treatments. As irrigation schedule depth was $60 \mathrm{~mm}$, application efficiency $\left(E_{a}\right)$ was highly achieved by applying $10.71 \mathrm{~m}^{3} \mathrm{~h}^{-1}$ in first irrigation and improved by all treatments in second irrigation due to increasing initial soil moisture content compared to first irrigation. Storage efficiency $\left(\mathrm{E}_{\mathrm{s}}\right)$ was properly achieved by applying all treatments except $10.71 \mathrm{~m}^{3} \mathrm{~h}^{-1}$ inflow rates under $0.05 \%$ furrow slope at first irrigation and $0.10 \%$ at second irrigation because almost $7 \%$ water deficit was occurred. 
Table 3: Infiltrated irrigation depth along furrow and its evaluation parameters.

\begin{tabular}{|c|c|c|c|c|c|c|c|c|}
\hline \multirow{3}{*}{$\begin{array}{c}\text { Irrigation } \\
\text { Furrow Slope, \% } \\
\text { Inflow rate, } \mathrm{m}^{3} \mathrm{~h}^{-1}\end{array}$} & \multicolumn{4}{|c|}{ First Irrigation } & \multicolumn{4}{|c|}{ Second Irrigation } \\
\hline & \multicolumn{2}{|c|}{0.05} & \multicolumn{2}{|c|}{0.10} & \multicolumn{2}{|c|}{0.05} & \multicolumn{2}{|c|}{0.10} \\
\hline & 10.71 & 5.35 & 10.71 & 5.35 & 10.71 & 5.35 & 10.71 & 5.35 \\
\hline Furrow length, $\mathrm{m}$ & \multicolumn{8}{|c|}{ Infiltrated irrigation depth $(\mathrm{mm})$} \\
\hline 0 & 52.8 & 64.5 & 50.2 & 62.9 & 46.9 & 57.4 & 49.9 & 53.9 \\
\hline 5 & 53.7 & 66.9 & 51.5 & 69.2 & 53.3 & 58.9 & 50.8 & 56.8 \\
\hline 10 & 54.2 & 72.0 & 54.9 & 74.3 & 60.8 & 62.3 & 52.1 & 60.8 \\
\hline 15 & 55.2 & 74.9 & 57.8 & 76.4 & 63.2 & 62.9 & 53.1 & 62.0 \\
\hline 20 & 56.7 & 78.9 & 60.0 & 81.0 & 63.9 & 62.6 & 53.7 & 64.3 \\
\hline 25 & 57.2 & 81.0 & 60.1 & 83.8 & 64.2 & 62.1 & 54.9 & 65.1 \\
\hline 30 & 57.7 & 80.6 & 61.7 & 86.0 & 63.9 & 61.7 & 57.1 & 66.4 \\
\hline 35 & 58.3 & 80.5 & 62.6 & 86.9 & 63.8 & 62.5 & 58.9 & 66.8 \\
\hline 40 & 57.5 & 79.4 & 62.5 & 86.6 & 63.2 & 62.6 & 59.4 & 67.3 \\
\hline 45 & 56.2 & 77.6 & 62.2 & 86.0 & 62.6 & 62.8 & 59.1 & 67.8 \\
\hline 50 & 55.1 & 75.2 & 61.8 & 84.4 & 62.1 & 62.0 & 58.9 & 67.5 \\
\hline 55 & 55.0 & 73.0 & 61.2 & 82.9 & 61.4 & 61.9 & 58.6 & 66.7 \\
\hline 60 & 54.2 & 72.5 & 58.7 & 81.8 & 60.7 & 60.9 & 58.7 & 65.8 \\
\hline${ }^{*} \mu, \mathrm{mm}$ & 55.7 & 75.2 & 58.9 & 80.2 & 60.8 & 61.6 & 55.8 & 63.9 \\
\hline $\mathrm{CV}, \%$ & 2.9 & 6.7 & 6.8 & 8.92 & 7.9 & 2.5 & 6.0 & 6.6 \\
\hline DU, $\%$ & 96.3 & 91.5 & 91.4 & 88.7 & 89.9 & 96.8 & 92.3 & 91.6 \\
\hline $\mathrm{UC}, \%$ & 97.5 & 94.2 & 94.2 & 92.3 & 93.2 & 97.8 & 94.8 & 94.3 \\
\hline$E_{a}, \%$ & 99.7 & 78.5 & 97.8 & 73.5 & 95.8 & 97.2 & 99.8 & 93.2 \\
\hline$E_{S}, \%$ & 92.5 & 98.3 & 96.0 & 98.3 & 96.9 & 99.8 & 92.7 & 99.3 \\
\hline
\end{tabular}

$* \mu$ is average infiltrated depth, $\mathrm{CV}$ is coefficient of variation, DU is distribution uniformity, UC is uniformity coefficient, $E_{a}$ is application efficiency, and $E_{s}$ is storage efficiency.

\subsection{Nitrogen distribution along furrow}

Nitrogen $(\mathrm{N})$ content as applied in irrigation stream using two different ways were illustrated in Figs. 2 and 3. Uniformity of $(\mathrm{N})$ was affected by furrow slope $(\mathrm{S})$, inflow rate $(\mathrm{Q})$ and nitrogen application method $(\mathrm{F})$. 
Results indicated that $(\mathrm{N})$ content in root zone decreased as furrow slope increased. Increase of furrow slope maximized infiltrated depth in which decreased $(\mathrm{N})$ concentration in root zone because of increasing $(\mathrm{N})$ with irrigation leaching. Applying $10.71 \mathrm{~m}^{3} \mathrm{~h}^{-1}$ inflow rate $(\mathrm{Q} 1)$ and $(\mathrm{N})$ from the beginning of irrigation (F1), minimum (N) content was 0.134 and $0.127 \%$ at $0.05 \%$ and $0.1 \%$ furrow slope, respectively; the maximum $(\mathrm{N})$ content was 0.144 and $0.134 \%$, respectively. On the other hand applying $(\mathrm{Q} 1)$ with $(\mathrm{N})$ when water advanced to the middle of the furrow $(\mathrm{F} 2)$, minimum $(\mathrm{N})$ content was 0.149 and $0.148 \%$ at $0.05 \%$ and $0.1 \%$ furrow slope, respectively, the maximum $(\mathrm{N})$ content was 0.163 and $0.159 \%$, respectively. Applying $5.35 \mathrm{~m}^{3} \mathrm{~h}^{-1}$ inflow rate $(\mathrm{Q} 2)$ and $(\mathrm{N})$ from the beginning of irrigation $(\mathrm{F} 1)$, minimum $(\mathrm{N})$ content was 0.147 and $0.131 \%$ at $0.05 \%$ and $0.1 \%$ furrow slope, respectively; the maximum $(\mathrm{N})$ content was 0.167 and $0.138 \%$, respectively. On the other hand applying (Q2) with $(\mathrm{N})$ when water advanced to the middle of the furrow (F2), minimum (N) content was 0.148 and $0.137 \%$ at $0.05 \%$ and $0.1 \%$ furrow slope, respectively, the maximum $(\mathrm{N})$ content was 0.168 and $0.146 \%$, respectively. For a given inflow rate and field slope, the acceptable uniformly $(\mathrm{N})$ distribution along furrow was occurred for $(\mathrm{F} 2)$ due to remaining most of $(\mathrm{N})$ in the plant root zone with less $(\mathrm{N})$ leaching. Results of $0.05 \%$ furrow slope, relative to $0.10 \%$ furrow slope, showed that nitrogen content was highly increased by applying the two inlet flow rates because fertilizer was more efficiently concentrated and distributed in the upper soil layer which most of plant roots existed.

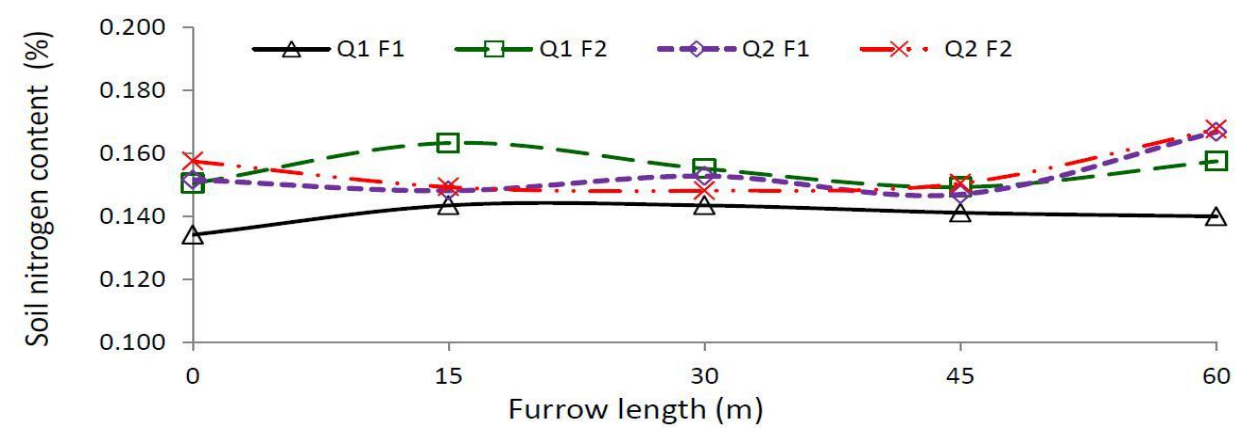

Fig. 2: Soil nitrogen content distribution along furrow under $0.05 \%$ furrow slope. 


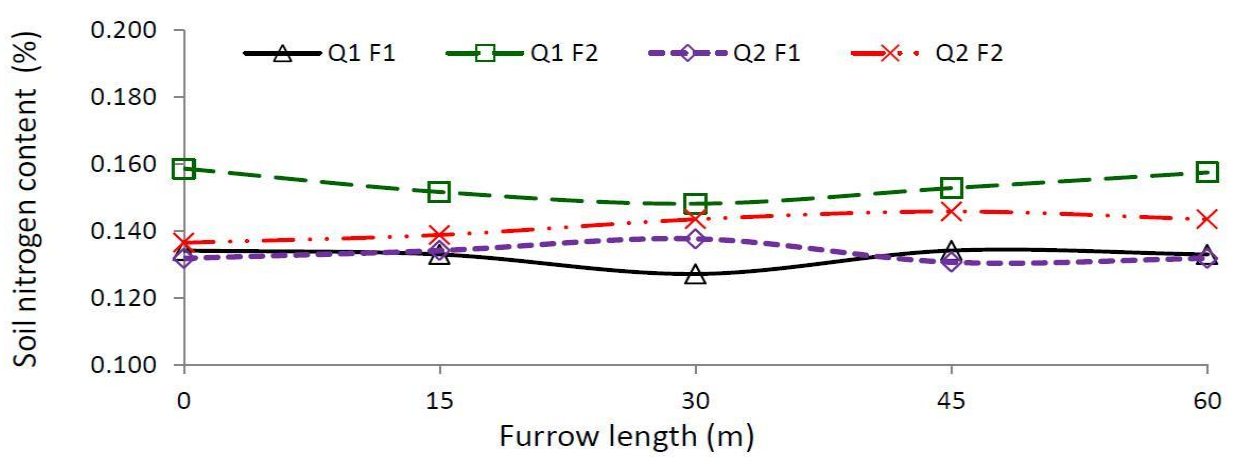

Fig. 3: Soil nitrogen content distribution along furrow under $0.10 \%$ furrow slope.

\subsection{Corn Productivity}

Grain yields by applying inflow rate and (N) application for 0.05 and $0.1 \%$ furrow slope are shown in Figs. 4 and 5. Green forage yield are, respectively, shown in Figs. 6 and 7. Grain and green forage yield were significantly affected by furrow slope, inflow rate and nitrogen application method. Corn grain yield along furrow was maximized in between 35 to $45 \mathrm{~m}$ furrow length due to optimizing water use. On the other hand, green forage yield was maximized at $45 \mathrm{~m}$ furrow length because infiltrated irrigation depth was higher at furrow downstream end. Corn grain and green forage yields were significantly higher for $0.05 \%$ furrow slope and by applying 5.35 followed by $10.71 \mathrm{~m}^{3} \mathrm{~h}^{-1}$ inflow rates under $(\mathrm{N})$ added when water advanced to the middle of the furrow treatment. It seemed that corn production was minimized at furrow upstream because of water deficit.

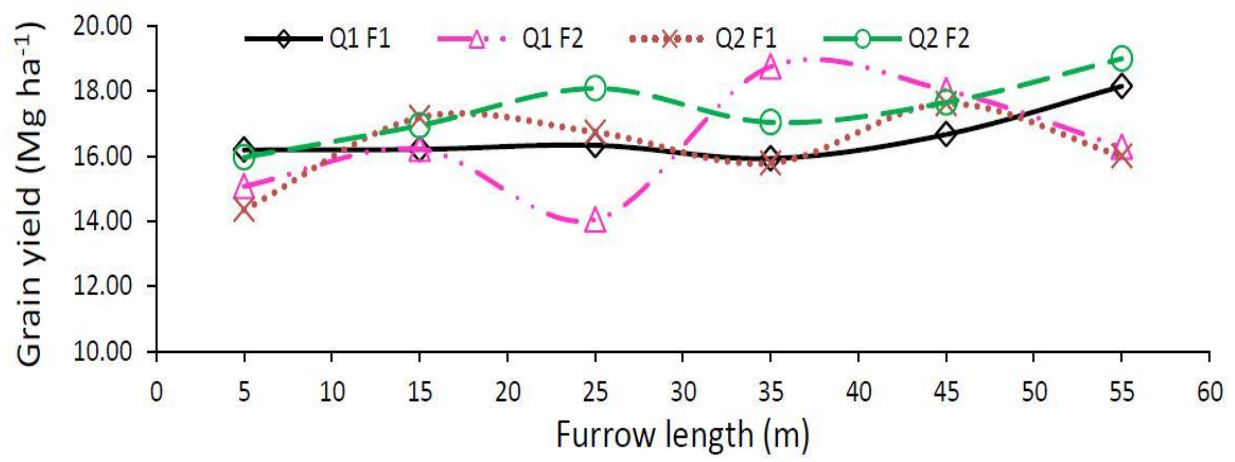

Fig. 4: Productivity of grain under $0.05 \%$ furrow slope. 


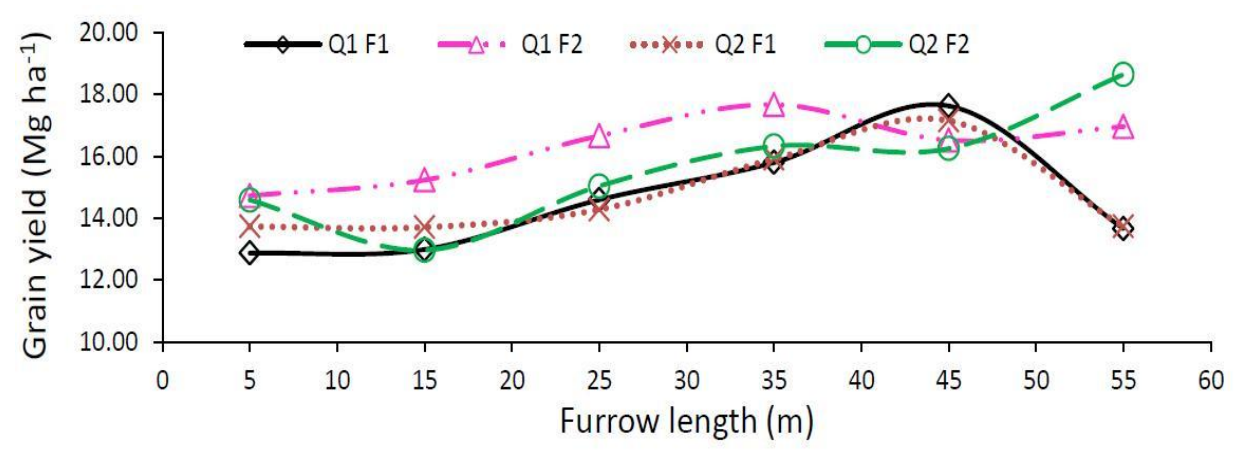

Fig. 5: Productivity of grain under $0.1 \%$ furrow slope.

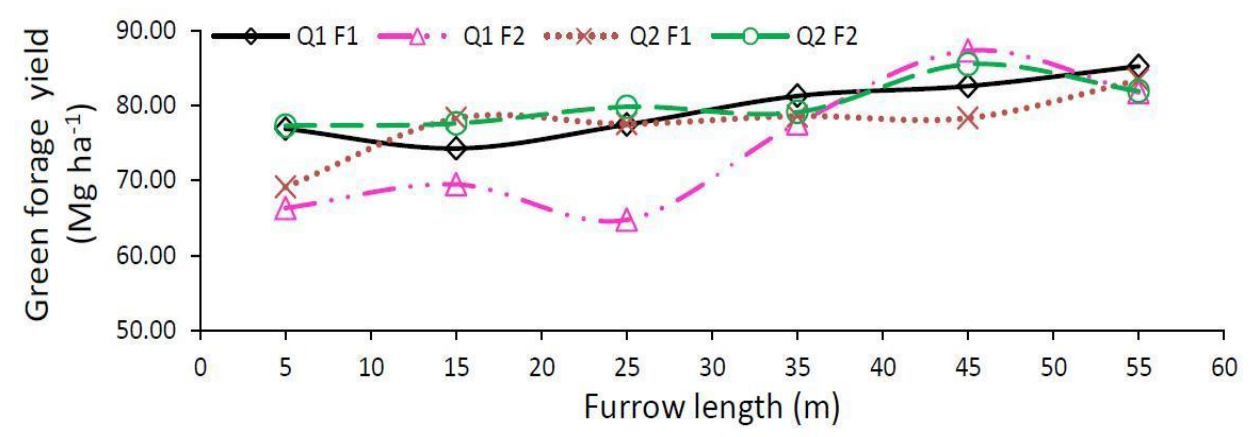

Fig. 6: Productivity of green forage under $0.05 \%$ furrow slope.

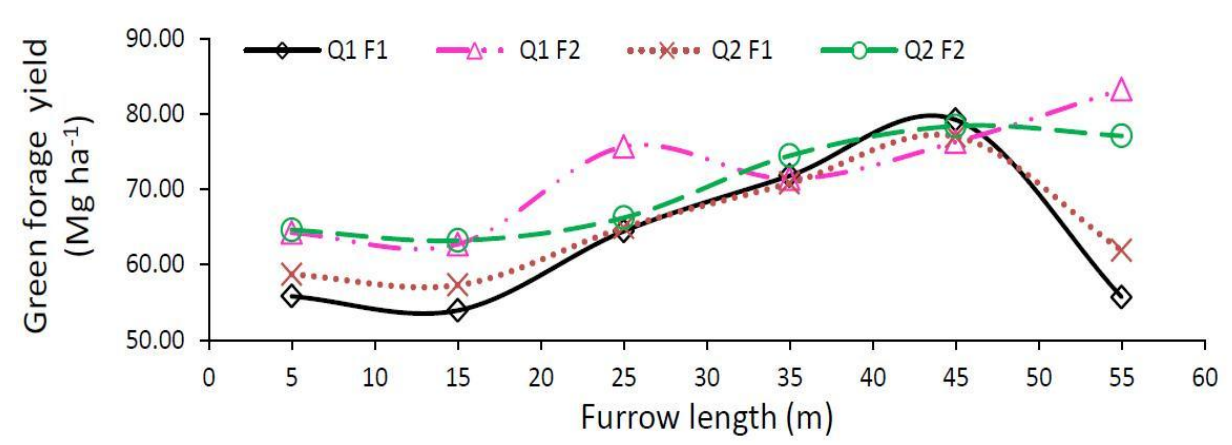

Fig. 7: Productivity of green forage under $0.1 \%$ furrow slope.

Corn yield, green forage yield, 100-grain weight, number of rows per ear and number of grains per row were statistically analyzed as shown in Table 4. Considering the effect of furrow slope, results were significantly 
affected by furrow slope. Results showed that corn yield, green forage yield, 100-grain weight, number of rows per ear and number of grains per row decreased by increasing furrow slope. Yield was generally increased by improving water uniformity and application. These results are in agreements of Amer (2009). Increasing of furrow slope from 0.05 to $0.10 \%$, used water was decreased as 6.51 and $0.11 \%$ at 10.71 and $5.35 \mathrm{~m}^{3}$ $\mathrm{h}^{-1}$ inflow rates, respectively. Based on the obtained results of this study, $0.05 \%$ furrow slope is recommended for the cultivation of corn crop. For a given slope and fertilizer method, results of corn were insignificantly affected by inlet flow rate. Results showed that corn yield, green forage yield, 100-grain weight, number of rows per ear and number of grains per row increased by decreasing inlet flow rate.

Table 4: Mean square, F value, and probability for grain and green forage yield, 100grain weight, number of rows per ear and number of grains per row.

\begin{tabular}{|c|c|c|c|c|c|}
\hline Item & $\begin{array}{c}\text { Grain yield } \\
\mathrm{Mg} \mathrm{ha}^{-1}\end{array}$ & $\begin{array}{c}\text { Green forage } \\
\text { yield } \\
\mathrm{Mg} \mathrm{ha}^{-1}\end{array}$ & $\begin{array}{c}\text { 100-grain } \\
\text { weight } \\
\mathrm{g}\end{array}$ & $\begin{array}{c}\text { No. of } \\
\text { rows per } \\
\text { ear }\end{array}$ & $\begin{array}{c}\text { No. of } \\
\text { grains per } \\
\text { row }\end{array}$ \\
\hline \multicolumn{6}{|c|}{ Mean square } \\
\hline $\mathrm{S}$ & 66.87 & 3386.5 & 320.8 & 30.2 & 44.734 \\
\hline $\mathrm{Q}$ & 0.138 & 8.72 & 0.036 & 0.39 & 0.389 \\
\hline $\mathrm{F}$ & 28.70 & 237.1 & 122.42 & 5.06 & 10.1 \\
\hline $\mathrm{S} * \mathrm{Q}$ & 3.51 & 8.19 & 0.76 & 6.89 & 10.5 \\
\hline $\mathrm{S} * \mathrm{~F}$ & 5.85 & 764.1 & 65.71 & 1.56 & 11.8 \\
\hline $\mathrm{Q}^{* \mathrm{~F}}$ & 0.61 & 18.8 & 0.036 & 1.27 & 3.1 \\
\hline $\mathrm{S} * \mathrm{Q} * \mathrm{~F}$ & 10.59 & 194.9 & 4.99 & 1.27 & 43.9 \\
\hline \multicolumn{6}{|c|}{ F value and probability } \\
\hline $\mathrm{S}$ & $36.9 *$ & $75.63 *$ & $142.98 *$ & $305.7 *$ & $8.33 *$ \\
\hline Q & 0.076 & 0.195 & 0.016 & $3.95 *$ & 0.072 \\
\hline $\mathrm{F}$ & $15.8^{*}$ & $5.294 *$ & $54.56 *$ & $51.16^{*}$ & 1.88 \\
\hline $\mathrm{S} * \mathrm{Q}$ & 1.94 & 0.183 & 0.339 & $69.63^{*}$ & 1.96 \\
\hline $\mathrm{S} * \mathrm{~F}$ & 3.221 & $17.1 *$ & $29.3 *$ & $15.79 *$ & 2.2 \\
\hline $\mathrm{Q}^{*} \mathrm{~F}$ & 0.336 & 0.419 & 0.016 & $12.79 *$ & 0.57 \\
\hline $\mathrm{S} * \mathrm{Q} * \mathrm{~F}$ & $5.84 *$ & $4.35^{*}$ & 2.225 & $12.79 *$ & $8.18 *$ \\
\hline
\end{tabular}

* Significant at $5 \%$, and ns is not significant.

$\mathrm{S}$ is furrow slope, $\mathrm{Q}$ is inflow rate, and $\mathrm{F}$ is nitrogen application. 
Decreasing of inflow rate from 10.71 to $5.35 \mathrm{~m}^{3} \mathrm{~h}^{-1}$, used water was decreased as 15.82 and $10.06 \%$ at 0.05 and $0.1 \%$ furrow slope, respectively. Based on the obtained results of this study, $5.35 \mathrm{~m}^{3} \mathrm{~h}^{-1}$ inlet flow rate is recommended for the cultivation of corn crop. These results are in agreement of those obtained by (Kassem and El-Khatib, 2000).

Considering the effect of nitrogen application method, results of corn were significantly affected by nitrogen application method, except green forage yield and number of grains per row. Results also showed that corn and green forage yields, 100-grain weight, number of rows per ear and number of grains per row increased when nitrogen was applied after offering half wave. Based on the obtained results of this study, nitrogen application after offering half wave is recommended for the cultivation of corn crop irrigated by furrow method.

\section{CONCLUSION}

The obtained results pointed out the following conclusions:

1- Increasing of furrow slope led to increase water recession time and irrigation depth.

2- Decreasing of inflow rate led to increase water advance time, water recession time and irrigation depth.

3- Irrigation uniformity and efficiency were improved for lower furrow slope $0.05 \%$.

4- Uniformity and efficiency increased by decreasing inflow rate at $0.05 \%$ furrow slope; in contrary at $0.10 \%$ furrow slope.

5- Nitrogen content in plant root zone decreased by increasing of furrow slope and improved by $(\mathrm{N})$ added after offering half wave.

6- Grain, green forage yields, 100-grain weight, number of rows per ear and number of grains per row significantly decreased by increasing furrow slope; insignificantly increased by decreasing inlet flow rate; and significantly increased by nitrogen application after offering half wave, except number of grains per row.

7- $0.05 \%$ furrow slope, $5.35 \mathrm{~m}^{3} \mathrm{~h}^{-1}$ inlet flow rate and nitrogen application after offering half wave are recommended for corn cultivation. 


\section{REFERENCES}

Abdul Rehman, Saleem, M. F.; Safdar, M. E.; Hussain, S. and Akhtar, N. (2011). Grain Quality, Nutrient Use Efficiency and Bioeconomics of Maize under Different Sowing Methods and NPK Levels. Chilean J. Agri. Res. 71, 586-593.

Alazba, A. A. (1999). Dimensionless Advance Curves for Infiltration. Families. Agricultural Water Management, 41, 115-131.

Amer, K. H. (2007). Surface Irrigation Evaluation Based on Analytical Interrelation among Water Infiltration, Advance and Recession. Proceeding of Irrigation Association, 9-11 December in San Diego, California, 433-445 pp.

Amer, K. H. (2009). The Possibility of Improving Surface Irrigation with Blocked End in Sparse Grape Trees. Misr J. Ag. Eng., 26, 836-862.

Amer, K. H. (2010). Corn Crop Response under Managing Different Irrigation and Salinity Levels. Agricultural Water Management 97, $1553-1563$.

Awad, M. A. and Gomaa, M. R. (2004). Precision Leveling Effects on Strip and Furrow Irrigations for Maize. Misr J. Ag. Eng., 21, 86102.

Black, C. A. (1982). Method of Soil Analysis. Soc. Agron. Inc. Pub., Madison, Washington, U. S. A. No. 9 Part 2.

Cetin, O. and Akinci, C. (2015). Effects of Drought on Optimizing Nitrogen Use of Winter Wheat in A semi Arid Region. Agriculture \& Forestry 61, 287-293.

Musick, J. T. and Duseek, D. A. (1980). Irrigation Corn Yield Response to Water. TRANS of the ASAE 23(1): 92-98.

DL Bjorneberg, (2013). Irrigation | Methods. USDA Agricultural Research Service, Kimberly, ID, USA.

http://dx.doi.org/10.1016/B978-0-12-409548-9.05195-2. 
Dooronbos, J. and Kassam, A. H. (1979). Yield Response to Water. FAO Irrigation Drainage Paper no. 33, FAO Rome, Italy, 193p.

Eck, H. V. (1984). Irrigated Corns Yield Response to Nitrogen and Water. Agron. J. 76: 421-428.

El Awady, M. N.; Tayel, S. A.; El Mawla, H. A. A.; El Lithy, A. M. and Mahmoud, A. M. (2009). Evaluation of Discharge Regulation in Gated Pipe Irrigation along Line. Irrigation and Drainage. The $16^{\text {th }}$ Annual Conference of the Misr Society of Ag. Eng., 1501-1512.

Estefan, G.; Sommer, R. and Ryan, J. (2013). Methods of Soil, Plant and Water Analysis: A manual for The West Asia and North Africa Region. International Center for Agricultural Research in The Dry Areas (ICARDA). Beirut, Lebanon. Third Edition. Page 22 and 83.

Fageria, N. K. and Baligar, V. C. (2005). Enhancing Nitrogen Use Efficiency in Corp Plants. Advances Agronomy 88, 97-185.

Foroud, N.; George, E. St. and Entz, T. (1996). Determination of Infiltration Rate from Border Irrigation Advance and Recession Trajectories. Agricultural Water Management 30, 133-142.

Gallais, A. and Hirel, B. (2004). An Approach to the Genetics of Nitrogen Use Efficiency in Maize. Journal of Experimental Botany 55, 295 306.

Hassan, S. S; Eid, S. F. M. and Mohammed, A. S. H. (2013). Some Engineering Effecting Surface Irrigation Using Gated Pipes for Sugarcane Production. Egypt J. Agric. Res., 91: 175-187.

Hastings Co., (1986). Gated Aluminum Irrigation Pipe. Hastings Co. Catalouge, Neberaska . U.S.A. http://hastingsirrigation.com/node/7

Holzapfel, E. A.; Marino, M. A. and Morales, J. C. (1984). Comparison and Selection of Furrow Irrigation Models. Agricultural Water Management, 9, 105-125. 
Howell, T. A.; Schneider, A. D. and Evett, S. R. (1997). Subsurface and Surface Microirrigation of Corn -Southern High Plains. Trans. Of the ASAE, Vol. 4(3): 635-641.

Jat, M. L.; Chandna, p.; Gupta, R.; Sharma, S. K. and Gill, M. A. (2006). Laser Land Leveling: A Precursor Technology for Resource Conservation. Rice-Wheat Consortium Technical Bulletin Series 7. New Delhi, India: Rice-Wheat Consortium for the Indo-Gangetic Plains. pp 48.

Kassem, M. A. and El-Khatib, S. I. (2000). Mathematical Determination of the Effect of The Major Engineering Factors on The Efficiency of Long Furrows Irrigation for Corn Crop. Misr J. Agric. Eng., 17, 569-588.

Koech, R.; Smith, R. and Gillies, M. (2010). Automation and Control in Surface Irrigation Systems: Current Status and Expected Future Trends. Southern Region Engineering Conference 11-12 November, Toowoomba, Australia.

Merriam, J. L. and Keller, J. (1978). Farm Irrigation System Evaluation: A Guide for Management. Third Edition Utah State University Logan.

Mohammed, A. S. H. (2008). Engineering Studies on Developing the Gated Pipes for Surface Irrigation in Small Holdings. Ph.D. Thesis, Agric. Eng. Dept. Fac. of Agric., Menoufia Univ.

Rodriguez, J. A. (2003). Estimation of Advance and Infiltration Equations in Furrow Irrigation for Untested Discharges. Agricultural Water Management 60, 227-239.

Smith, R. J.; Watts, P. J. and Mulder, S. J. (1986). Analysis and Design of Gated Irrigation Pipelines. Agricultural Water Management, 12, 99115. 
Undersander, D. J.; Marek, T. H. and Clark, R. N. (1985). Effect of Nozzle Type on Runoff and Yield of Corn and Sorghum under Center Pivot Sprinkler Systems. Irri. Sci. (6): 107-116.

Walker, W. R. and Skogerboe, G. V. (1987). Surface Irrigation: Theory and Practice. Prentice-Hall, Englewood Cliffs, NJ 07632, 386 pp.

Zhu, Z. L. and Chen, D. L. (2002). Nitrogen Fertilizer Use in ChinaContributions to Food Production, Impacts on The Environment and Best Management Strategies. Nutrient Cycling in Agroecosystems, 63, 117-127.

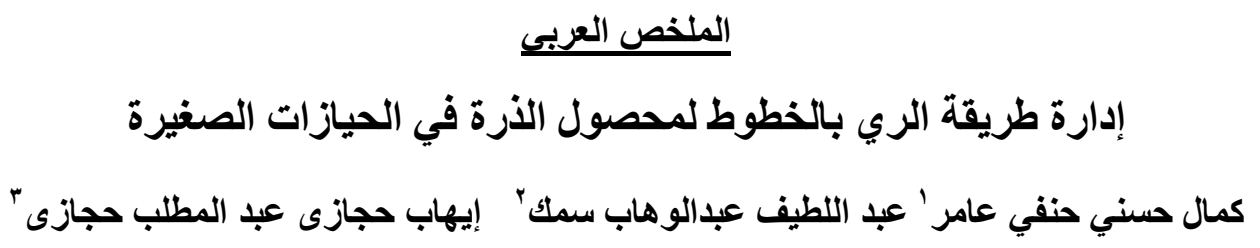

تم إجر اء التجربة بمزرعة الراهب ـ مزرعة كلية الزراعة جامعة المنوفية وكان نوع التربة

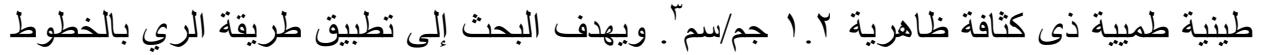

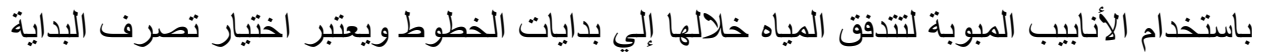
وميل خط الري وطريقة إضافة الأسمدة وتوزيعها من العوامل التي التي ترفع من كفاءة الرياي

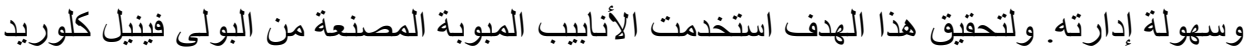
لري التجربة. وكانت المعاملات لهذه الدراسة هى استخدام ميلين مختلفين لسطح التربة التية (PVC)

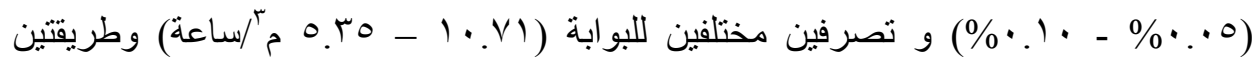
لإضافة السماد مع مباه الري (إضافة السماد مع بداية نزول المياه للحقل - إضافة السماد بعد تقدم نصف الموجة).

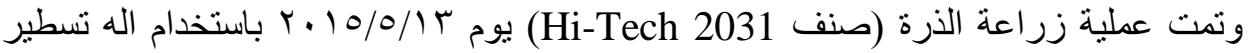

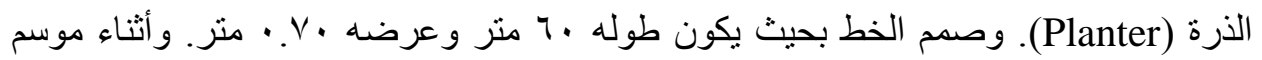

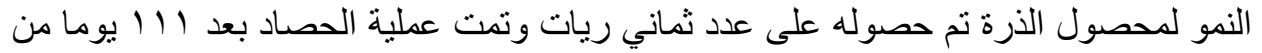
زراعته.

\footnotetext{
(1) (أستاذ الهندسة الزر اعية ـ كلية الزر اعة ـ جامعة المنوفية

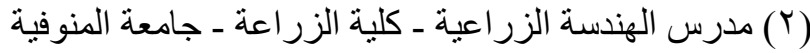

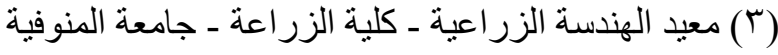


بمكن تلخيص أهم النتائج المتحصل عليها لمحصول الذرة على النحو التالي:

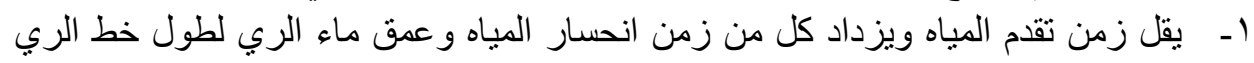
بزيادة ميل الخطوط. ז- ـ يزداد زمن تقدم المياه وزمن انحسار المياه و عمق ماء الري لطول خط الري بانخفاض التصرف. r- تزداد قيمة معامل الاختلاف CV وتقل قيمة كل من انتظامية التوزيع DU و معامل التجانس و وكفاءة الري بزيادة ميل الخطوط.

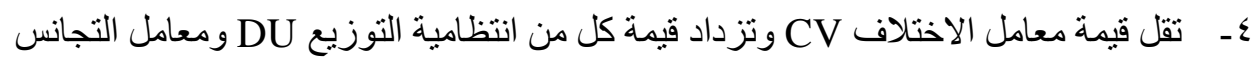

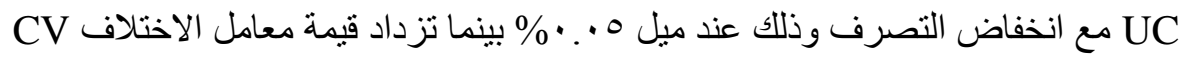

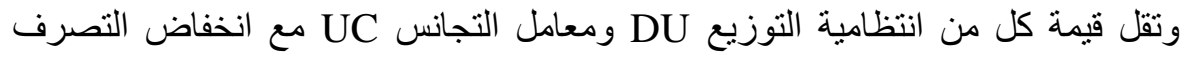

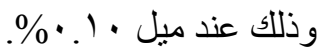
ــ متوسط المحتوى النيتروجينى بالتربة يقل بزيادة الميل بينما يزداد بتطبيق النبتروجين بعد تقدم نصف موجة المياه. 7- وجود فروق معنوية بسبب ميل الخط لكل من محصول الحبوب ومحصول القش الأخضر

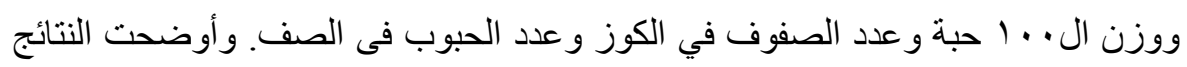

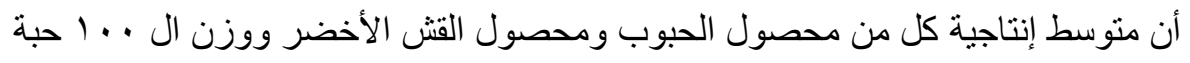
و عدد الصفوف فى الكوز و عدد الحبوب في الصف الو احد يقل بزيادة ميل الخط.

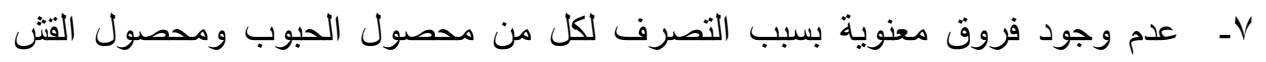

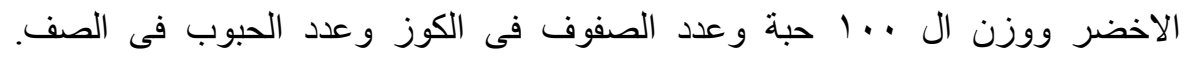

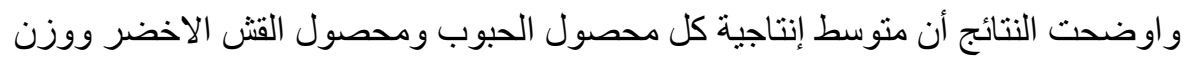
ال . . . حبة وعدد الصفوف فى الكوز وعدد الحبوب فى الصف يزداد بانخفاض التصرف. 1ـ وجود فروق معنوية بسبب نطبيق السماد لكل من محصول الحبوب ووزن ال . . 1 حبة

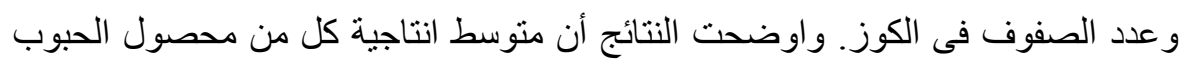

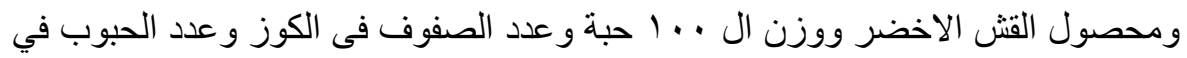
الصف يزداد بتطبيق السماد بعد تقدم نصف الموجة.

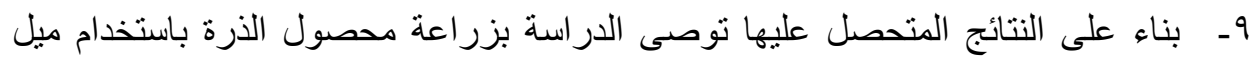

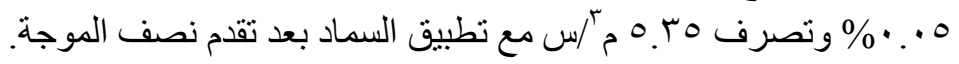

